\title{
EVALUATION OF THE ASSESSMENT INFORMATION SYSTEM PROGRAM (ISP) BANDUNG JUARA IN THE GOVERNANCE SECTION OF THE REGIONAL SECRETARIAT OF THE CITY OF BANDUNG
}

\author{
By \\ Nyi Raden Ruyani', Andre Ariesmansyah ${ }^{2}$, Elika Dewi Faustine ${ }^{3}$ \\ ${ }_{1,2}$ Department of Public Administration, University of Pasundan, Indonesia \\ ${ }^{3}$ Student of Department of Public Administration, University of Pasundan, Indonesia \\ Email: ${ }^{1}$ ruyani@unpas.ac.id, ${ }^{2}$ andre.ariesmansyah@unpas.ac.id, ${ }^{3}$ elika.dewifsn@gmail.com
}

\begin{tabular}{l}
\hline \hline Article Info \\
\hline Articlehistory: \\
Received Nov 11, 2021 \\
Revised Dec 25, 2021 \\
Accepted Jan 28, 2022
\end{tabular}

Keywords:

Program Evaluation

Assessment Information

System

Public Service

\begin{abstract}
Every government either central or regional is often required to always innovate, especially in the activities of qualified public servants. One of them is innovation whose activities are spread across each region in the city of Bandung is the Bandung Champion Assessment Information System (SIP), which is a program built to assess the performance results of each camat and lurah in public service, the implementation of evaluation is measured based on the results of the activity report uploaded to the SIP Bandung Champion website, camat and lurah evaluation activities have several stages to get the final results of the assessment. The purpose of this research is to analyze and describe the Evaluation of The Bandung Champion Assessment Information System (SIP) Program in the Governance Section of the Bandung City Regional Secretariat to know.

The research method used is qualitative with a descriptive approach. Data collection techniques are used with literature studies, observations, documents and interviews. To measure the evaluation of SIP program Bandung Champion researchers use the Program Evaluation Theory which has indicators Of Evaluation Context, Evaluation Input, Evaluation Process, Product Evaluation (CIPP).

This research, that the evaluation of the Bandung Champion SIP Program has problems in performance has not been maximal, citizen assessment activities are not realized.
\end{abstract}

Thisisan open accessarticleundertheCC BY-SAlicense.

\section{CorrespondingAuthor:}

Nyi Raden Ruyani,

Department of Public Administration,

University of Pasundan,

68 Lengkong Besar Road, Bandung City, West Java, Indonesia.

E-mail: ruyani@unpas.ac.id

\section{INTRODUCTION}

Indonesia has started a new order after the formation of the era of bureaucratic reform, where one of the government's efforts to achieve changes or improvements in the country or society is the system in the political, social, religious, etc. fields. Of course this is nothing but aiming at an achievement, namely to achieve good governance, good governance, namely being able to protect and be fully dedicated to the community, of course it requires hard work coupled with commitment from stakeholders and support society itself.

Looking at the affairs of how well the government's achievements are to the community, namely through public services, of course quality public services must be in accordance with service standards or standard operating procedures for services (SOPP) that have been prepared and then become references and benchmarks, so that the realization of their respective functions and accountability in serve. As quoted by Agung Kurniawan (2013: 128) in Noor Halimah stated that public service is an activity of giving and serving the needs of the public with different interests. 
The Bandung Champion Assessment Information System is an internet-based electronic Assessment Information System for evaluating the performance of sub-district and village heads with a period of one year. The program is one of the benchmarks for evaluating the quality of performance in the region, namely by the sub-district and village heads by carrying out performance in carrying out a development related to improving public services.

Bandung Mayor Regulation 036 of 2019 concerning Procedures for Performance Evaluation of Camats and Lurahs Number 1354 of 2014 concerning performance appraisals of Camats and Lurahs throughout the City of Bandung, but along with its development, Government Regulation No. 17 of 2018 which is about the District (in the regulation of the Mayor of Bandung 036 of 2019). The assessment was carried out by the assessment team and by the Governance Section of the Bandung City Regional Secretariat in providing an assessment and monitoring of the performance results of public services carried out by the Bandung City District and Urban Village Apparatus online which can be accessed via the website or portal.http://sip.bandung.go.id/.On in 2014-2015 the public can participate in assessing and accessing, of course the program is a forum for creating transparency, friendliness, safety, and how accountable the apparatus is in carrying out their duties in services at the sub-district and kelurahan levels. However, the assessment did not run effectively until now the assessment carried out by the community has not been carried out again.

Assessment Information System Program (SIP) Bandung Champion of course the assessment is done online, but there are still field surveys and there are results of exposure. This program is implemented with access from sub-district heads and lurahs by uploading regional profiles, activity results and data in the form of monthly to annual reports and the results will be evaluated. In fact, the evaluation results in the report by describing the predicate of the final results after having several stages are classified with 3 (three) sub-districts and 3 (three) best sub-district heads based on the qualifications that have been determined and seen based on the Assessment Information System Review (SIP) Bandung Champion, Although the entire Bandung City Region has 30 subdistricts and 151 sub-districts as well as the sub-district heads will receive report cards from the final results of performance by carrying out the activities that have been determined and have been carried out, the final results of the overall evaluation of the sub-district heads will be reported to the mayor. Stufflebeam (1993) in Eko Putro Widoyoko, There are four approaches in implementing the evaluation process, including; Context evaluation (context evaluation), Input evaluation (input evaluation), Process evaluation (process evaluation), Product evaluation (product/outcome evaluation). 


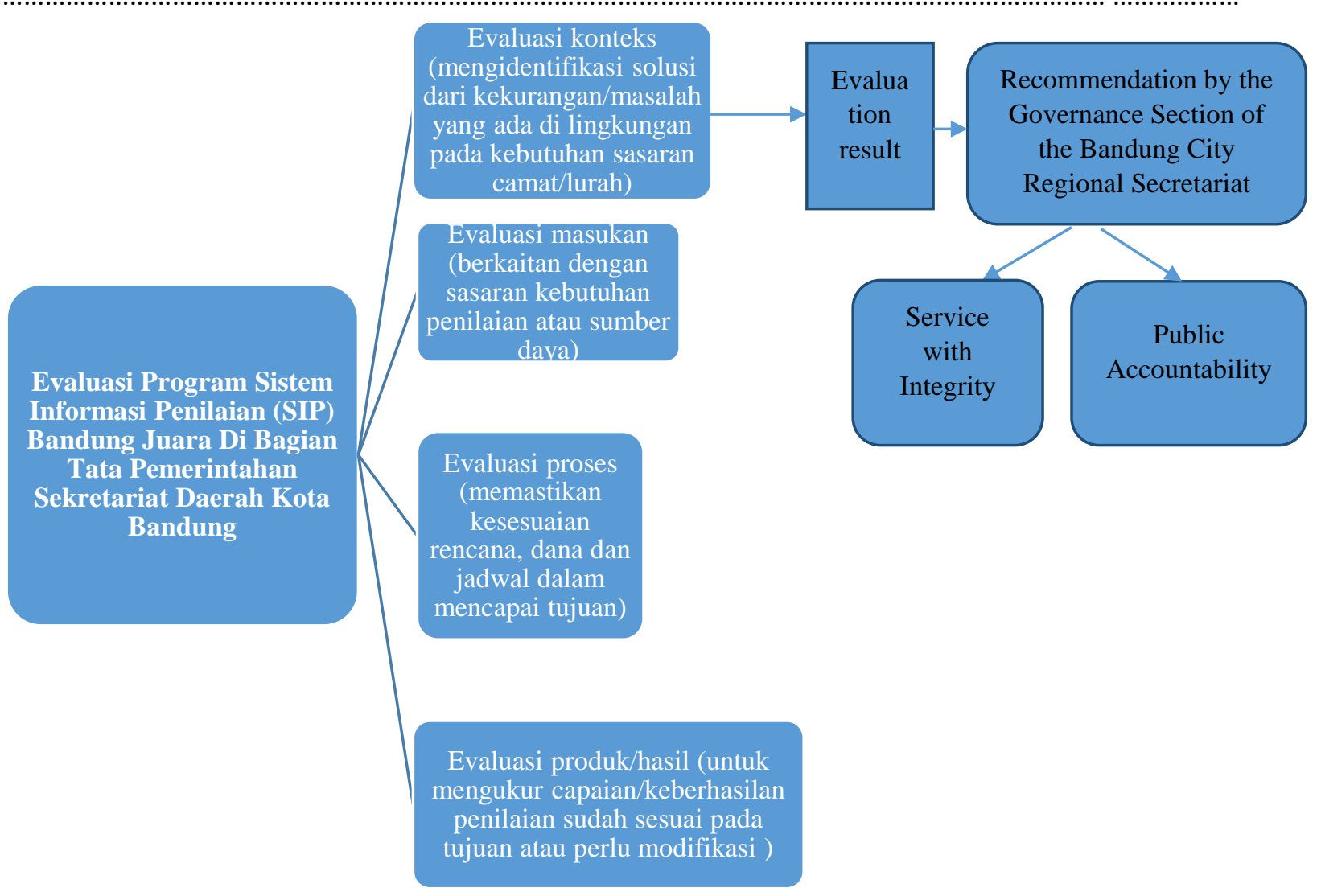

Figure 1. Research Framework Chart

\section{RESEARCH METHOD}

This research was carried out to find out, examine more deeply the obstacles or problems, achievements, as well as how to assess or evaluate the process of evaluating the SIP Bandung Champion program in carrying out services, so this research has a focus on program evaluation. The research used a qualitative descriptive approach. Sugiyono (2012) stated that descriptive is a method used in describing or analyzingresearch results but not used for broader conclusions.

Collecting data and information obtained through observation, documentation, interviews, and discussions. As quoted by Bogdan and Taylor (1992: 21) that qualitative research is a research process by generating descriptive data in the form of discussions, taking notes, the behavior or behavior of the people to be observed, thereby enabling a deeper understanding of reality based on deductive thinking process.

This research can be seen by researchers exploring problems in the Evaluation of the Assessment Information System Program (SIP) Bandung champion, with that goal is expected to be achieved. Researchers limit the use of four indicators to see how successful the Bandung Champion SIP program is, namely: Context Evaluation (Context Evaluation), Input Evaluation (Input Evaluation), Process Evaluation (Process Evaluation), Product Evaluation (Product Evaluation / Results) So it can be concluded that qualitative research on the implementation focuses on the field with observation, until interviews, then all data and information can be poured into descriptive form in research.

This research can be seen by researchers exploring problems in the Evaluation of the Assessment Information System Program (SIP) Bandung champion, with that goal is expected to be achieved. Researchers limit the use of four indicators to see how achieved the Bandung Champion SIP program is: Context Evaluation (Context Evaluation), Input Evaluation (Input Evaluation), Procss Evaluation (Process Evaluation), Product Evaluation (Product/Outcome Evaluation). 
Table. 1 Operational Variable

\begin{tabular}{|c|c|c|c|}
\hline Variable & Indicator & Parameter & Data source \\
\hline \multirow{4}{*}{$\begin{array}{l}\text { Evaluation of the } \\
\text { Assessment } \\
\text { Information } \\
\text { System Program } \\
\text { (SIP) Bandung } \\
\text { Champion }\end{array}$} & $\begin{array}{c}\text { Context evaluation } \\
\text { (context evaluation), }\end{array}$ & $\begin{array}{l}\text { Includes an analysis of environmental } \\
\text { conditions, or an assessment team of } \\
\text { regional government agencies, } \\
\text { program goals and objectives to be } \\
\text { achieved }\end{array}$ & $\begin{array}{l}\text { Staff of the } \\
\text { Administration of } \\
\text { the Regional } \\
\text { Secretariat of the } \\
\text { City of Bandung- }\end{array}$ \\
\hline & $\begin{array}{l}\text { 2. Input evaluation } \\
\text { (input evaluation) }\end{array}$ & $\begin{array}{l}\text { Coverage of human resources, } \\
\text { supporting equipment, sources of funds } \\
\text { (budget) activities, benefits of the } \\
\text { Bandung SIP Champion program }\end{array}$ & \multirow{3}{*}{$\begin{array}{l}\text { Staff of the } \\
\text { Administration } \\
\text { Section of the } \\
\text { Bandung City } \\
\text { Regional } \\
\text { Secretariat - and } \\
\text { Residents in the } \\
\text { Bandong City } \\
\text { Region }\end{array}$} \\
\hline & $\begin{array}{l}\text { 3. Process evaluation } \\
\text { (process evaluation) }\end{array}$ & $\begin{array}{l}\text { The program design process, program } \\
\text { implementation, who, when and the } \\
\text { obstacles that occur in program } \\
\text { implementation }\end{array}$ & \\
\hline & $\begin{array}{l}\text { 4. Product evaluation } \\
\text { (product/outcome } \\
\text { evaluation). }\end{array}$ & $\begin{array}{l}\text { Achievement/success, context, input, } \\
\text { strengthsandweaknesses, and long- } \\
\text { term impact }\end{array}$ & \\
\hline
\end{tabular}

\section{RESULTS AND ANALYSIS}

The results of this study use the program evaluation theory, namely the CIPP evaluation model created by Stufflebeam (1993) which was stated by Eko Putro Widoyoko (2017), suggesting 4 (four) approaches, namely Context Evaluation (Context Evaluation), Input Evaluation (Input Evaluation), Process Evaluation (Process Evaluation), Product Evaluation (Product/Outcome Evaluation). With these evaluation models, the SIP Bandung Champion Program can try to provide performance and service results based on the evaluation results.

Assessment Information System Program (SIP) Bandung Champion. SIP Bandung Champion is one of the breakthroughs in the development of the Bandung City Government in E-Governance innovation, namely:(1) Become a means of implementing district and sub-district performance assessments,(2) As well as a means of reporting the activities of the sub-district and village heads, (3) While going through the evaluation stage and reviewing the performance results in the regional scope by the sub-district and village headsEvery process of reporting and evaluating performance results has been adjustedthe mechanism is in the Mayor's Regulation Number 036 of 2019 concerning Procedures for Evaluation of the Performance of the Camat and Lurah which is carried out with the aim of being able to measure the results of performance achievements in each activity, in order to be able to evaluate each task implementation of each sub-district and sub-district, directing a sustainable direction in every coordination of the sub-district head. and the integration of performance between government administrators in the region with the general policies of the Regional Government.

1) Context Evaluation (context evaluation) 
International Journal of Social Science (IJSS)

Vol.1 Issue.5 February 2022, pp: 775-784

ISSN: 2798-3463 (Printed) | 2798-4079 (Online)

DOI: https://doi.org/10.53625/ijss.v1i5.1322

Evaluation of this context can be described in terms of analysis of environmental conditions or aspects that can be assessed through surveys in determining problems at SIP Bandung Champion, context evaluation describes aspects of program objectives with any needs in order to achieve goals can be achieved.

The aim of the Bandung SIP Program is to win the assessment at the regional level of Bandung City, which is to be able to weigh and evaluate the performance of the sub-district and lurah in order to fulfill the implementation of local government activities and to be able to assess the conditions found in each government activity for the sub-district and kelurahan.

\section{2) Input Evaluation (input evaluation)}

This input evaluation includes the scope of sources, supporting infrastructure, alternatives to sources of funds or budget for each activity, then the benefits of the program, as well as input from the public in receiving services. This can be the evaluator's input on the SIP Bandung Champion Program and the existing statements so that if there are problems they can encourage problem solving to the program.

Overall, the activities that have been carried out are of course supported by the infrastructure, one of which requires a budget. In every activity, the sub-district and lurah activities require funds or a budget for its implementation which has been stipulated in the Mayor's Regulation no. 036 of 2019 concerning Procedures for Evaluation of Camat and Lurah Performance in Chapter VII article 10 concerning Financing. On the results of the budget interview for the SIP Bandung Champion activities carried out by the sub-district and village heads, Mrs. WidyPurinadjati as treasurer said:

"The budget is definitely obtained from the Bandung City Regional Revenue and Expenditure Budget (APBD), the budget is used by the Camat and Lurah for spending on goods and services such as shopping for banners, brochures, pamphlets, banners and other information facilities, also used for performance facilities in the government. Territory and for activities related to public services"

There is also input from the interview, then the researcher conducts an interview about the activity of the process of fulfilling service activities from one of the residents of the service activities in the sub-district he received, namely by Mrs. SennyNursalamah in Cibenying District, she said:

"Sometimes, for example, if you need a signature from the Lurah or Camat, it takes a long time, the reason is like the Camat or Lurah is not yet at the office, even though it's already working hours. The logic is that if there is a meeting or other activity, they can speak so that the residents don't have to wait, while sometimes it's not clear when they are told to wait a long time."

As soon as he said, from the results of the interview, the constraints and shortcomings of SIP Bandung The champion in carrying out public services is still not satisfactory, this problem must be addressed and needs to be reevaluated by the stakeholders, namely the assessment team, renewal is needed so that the service and performance of the sub-district and lurah can run as effectively as possible.

3) Process Evaluation (process evaluation),

Evaluation of this process is from the results of the program design process, to program implementations, the process of data collection and the implementation team, when and the obstacles that occur in each program implementation. This evaluation process can direct how far the Bandung Champion SIP Program is implemented according to plan. Mr. HandikaDevara as the one who held and participated in the assessment of SIP Bandung Champion said about the implementation of uploading work results:

"In uploading the results of the activity reports, of course the timeliness has been regulated in Mayor Regulation Number 036 of 2019 concerning Procedures for Appraisal of Camat and Lurah Performance in Article 7 Paragraph (3) for the deadline for submitting reports, namely, monthly reports is reported no later than the 5th. In the following month, while the annual report is reported on October 10 at the end of the assessment period, as well as for the following years".

\section{4) Product Evaluation(product/result evaluation)}

This evaluation sees and can measure the success of the goals that have been set by the program, seeing the strengths and weaknesses of the activity, it can be useful so that the evaluation of the results can help the SIP Bandung Champion Program make decisions in renewing, or continuing until the program can be stopped, therefore product evaluation or results determine long term impact. From public service activities, based on the results of interviews as staff at the Regional Secretariat of Bandung City Administration by Mr. HandikaDevara as the one who holds and participates in evaluating the Bandung SIP Champion, he said:

"The service assessment activity in the SIP program web in 2014-2015 was actually able to participate in assessing and giving opinions on the work of the sub-district and village heads, even though at that time there were very few participants, because there were still many people who did not know about the program. However, now the service assessment activities on the Bandung SIP website Champion 
residents no longer play a role in the assessment because indeed the results of the assessment carried out by the public do not know what to recap on the assessment points, which are why the assessment activities by residents are no longer running".

Evaluation models are Context Evaluation, Input Evaluation, Process Evaluation, and Product/Outcome Evaluation. This evaluation approach is oriented towards decision making, so that it can help any leader or administrator and make it easier for researchers to see the achievements of the SIP Bandung Champion Program as an alternative in decision making and problem solving.

\section{5) The process of implementing the Bandung SIP Assessment Champion}

The initial stage of the Bandung Champion SIP assessment has a weight of $60 \%$ from the results of the monthly value and the annual value of performance uploaded by the sub-district and village heads and then from the data to documents, an assessment is carried out by the assessment team, namely in the Governance Section. The SIP Bandung Champion assessment is always carried out every one year period, namely November to October, in the 2019 period an evaluation is carried out in November 2019 to October 2020 and every subsequent year it is carried out in the same month.

The next assessment process is to conduct a field survey which has a weight of $20 \%$. However, in 2020 it is not possible to carry out the field survey assessment, considering that due to the Covid-19 pandemic, the weight of $20 \%$ of the field survey was drawn to the process of exposure value which initially had a weight of only $10 \%$ and then became $30 \%$. Then the final assessment stage, namely the value of the leadership policy has a weight of $10 \%$

The assessment is usually carried out by taking 15 sub-districts and 15 sub-districts and then in the implementation of the results of the presentation it is narrowed back into the 10 best sub-districts and 10 best lurahs, until the final assessment is determined, namely the decision is submitted by the Mayor of Bandung, the determination of the final results of the best performance evaluation is determined by the 3 best sub-districts and The 3 best lurahs are included in the minutes of the event.

6) Implementation of SIP Bandung Activities Champion

In the Bandung SIP Program, the camat and lurah champions perform several performances and carry out public services. There are activities as well as several assessment report instruments that must be done and then it is mandatory to upload them to the SIP BDG Champion Web by every Camat and Lurah throughout the City of Bandung to determine how well each sub-district and lurah perform in manifesting their performance.

\section{Figure 1 Bandung City Assessment Information System}

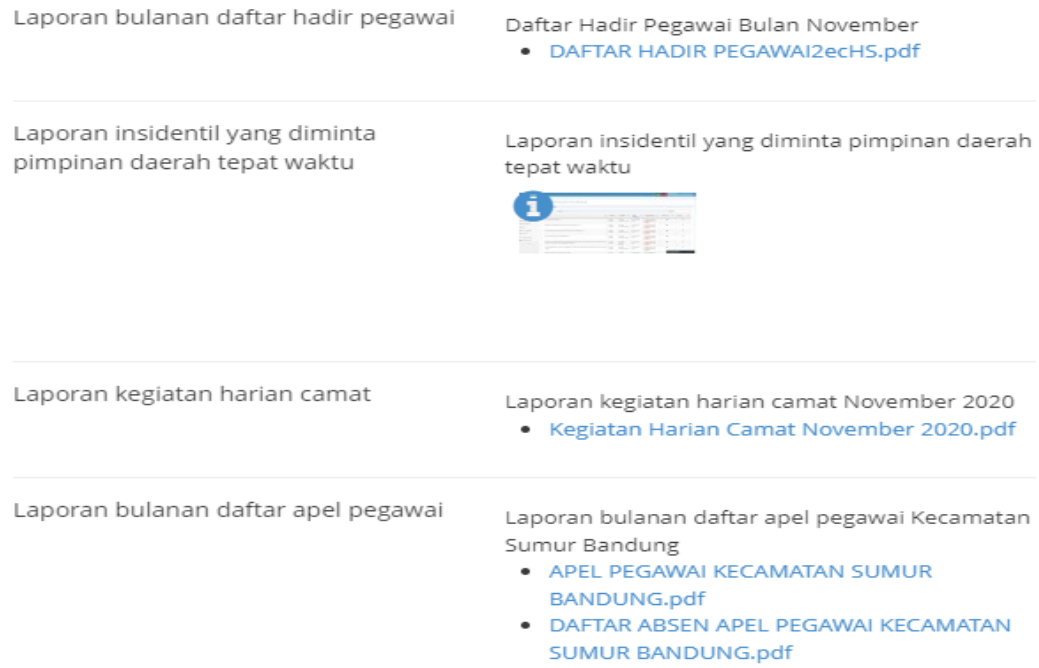


International Journal of Social Science (IJSS)

Vol.1 Issue.5 February 2022, pp: 775-784

ISSN: 2798-3463 (Printed) | 2798-4079 (Online)

Penyelenggaraan pelayanan di Kecamatan

Aktifitas Laman Website dan Media Sosial Kecamatan

Data sarana prasarana, fasum dan fasos di Kecamatan

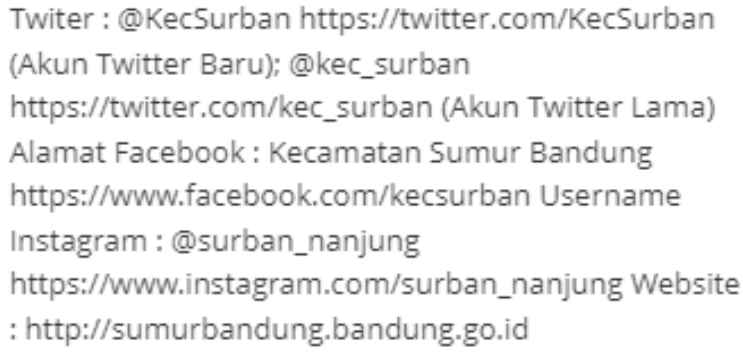

Persentase Sarana pendidikan di wilayah Kecamatan Bandung

Wetan yang tertinggi adalah Sekolah Dasar dengan $34 \%$, sementara Persentase Sarana Kesehatan yang ada di Wilayah Kecamatan Bandung Wetan yang tertinggi adalah Posyandu sebanyak $79 \&$ dan untuk Prasarana Ibadah di Wilayah Kecamatan Bandung Wetan paling tinggi adalah Masjid dengan $549 \%$
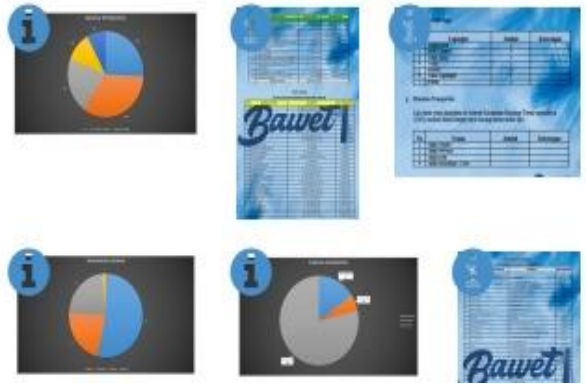

Figure 2 Implementation of the Bandung City Assessment Information System

From some of the pictures above, it can be concluded that every sub-district and village head is required to upload it to the SIP Bandung Champion Web as an assessment facility and as an evaluation material which is presented in the form of real evidence in the form of photos, document files, links and others. Each activity report is proof that these activities are nothing but the aim of protecting, serving citizens in public service activities, maximizing every public facility, the environment of each region in the city of Bandung.

The performance of all sub-districts and lurahs is also shown based on the assessment of report cards. The report cards obtained by assessment are the results of good performance, moderate performance and poor performance, along with the results of the percentage of report cards obtained by the sub-district and village heads 
Figure 3 Percentage of Sub-District Performance Graph Based on Report Report

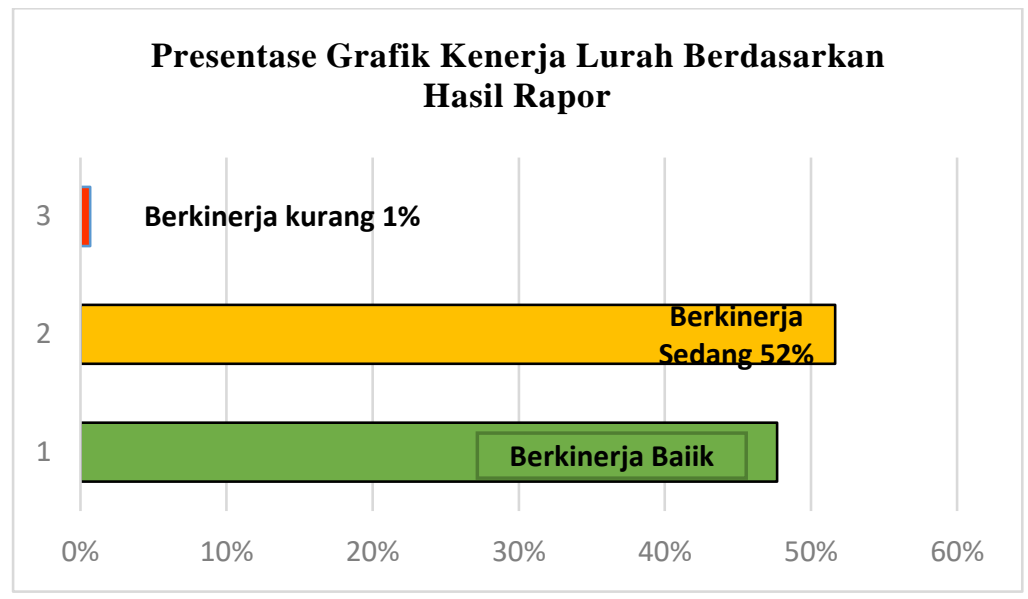

The percentage graph above for the results of all sub-district and lurah assessments in 2020 can be shown that the results of the performance of the camat performing well have a percentage of $63 \%$ and $37 \%$ performing moderately and not having the performance of the camat having an underperforming assessment percentage. Meanwhile, the percentage of Lurah's performance with good performance has a percentage of $48 \%$, 52\% with moderate performance and $1 \%$ underperforming.

From the results of the performance of each sub-district and village head that has been uploaded to the Assessment Information System (SIP) Bandung Champion, the assessment team can see and evaluate whether the work has been carried out optimally or not, of course the assessment team will verify or check the truth in the field and provide an explanation by each sub-district and village head.

\section{CONCLUSION}

The evaluation activity has four stages, namely the assessment stage of SIP Bandung Champion in the monthly assessment and annual value, the field survey stage, the exposure value stage, and the policy value stage, each of which has a weight in its assessment aspect until the final results of the sub-district and lurah performance evaluation are determined from the results. Mayor's regulatory policy, with the result that the best 3 (three) subdistrict heads and the best 3 (three) lurahs, of course, who have the best assessments will get rewards. Assessment evaluation activities are carried out by several assessment teams. Then all sub-districts and lurahs will receive a report on the results of their performance for a period of one year with a description of their assessment that is performing well.

The implementation of SIP Bandung Champion is one of the e-governance innovations in terms of evaluating performance results in the regions, namely the Camat and Luarah, basically the program facilitates regional government activities in carrying out performance evaluations for the Camat and Lurah. Because in the SIP 
International Journal of Social Science (IJSS)

Vol.1 Issue.5 February 2022, pp: 775-784

ISSN: 2798-3463 (Printed) | 2798-4079 (Online)

DOI: https://doi.org/10.53625/ijss.v1i5.1322

Bandung Champion program, each of the 30 sub-districts and 151 urban villages are required to always upload, report their performance results in the form of photos, file data into the SIP Bandung Champion web for each monthly reporting period and annual report. Aspects of the assessment are in the form of service quality index activities, quality of cleanliness, orderliness, beauty of the environment and the implementation of service activities to the implementation of other general government tasks.

Even though it is supported by the application of technology, the Bandung Champion SIP evaluation program still has problems including the results of the sub-district and lurah assessment performance results that have not yet achieved maximum results and then there are still problems with the server, also the current situation is the Covid-19 pandemic so that some activities in the field will be a little bit stuck. Another obstacle is the assessment of citizens on the SIP Bandung Champion website is now not carried out due to the results of the assessment of residents who do not know which point of assessment will enter so that the assessment of citizens has not become an indicator to measure the performance results of each sub-district and lurah and there are still many residents who do not know and do not understand the program, because of the lack of optimal socialization by government officials in the dissemination of SIP Bandung Champion, then the lack of info and explanation about the assessment program on the SIP Bandung Champion web page. Therefore, it is necessary to evaluate in improving the performance of the sub-district and village heads and the Bandung Champion SIP Program can be renewed into a transparent system for the community.

\section{ACKNOWLEDGEMENTS}

Regarding the performance of the sub-district and village heads, there is a need for evaluations that can update and improve the quality of their performance in fulfilling all activities, making performance more accountable, especially in service so that it is maximized. Also the solution that Diskominfo hopes can provide greater storage for the Bandung Champion SIP server".

In terms of assessment instruments by residents, it is necessary to update and coordinate so that the results of the assessment can be used as a measurement of the performance of each sub-district and village and each citizen's assessment results can actively operate again along with the results of the residents' assessments that can be displayed on the web which will be a benchmark for services in the region and the community. can continue to participate in conducting assessments of course this can result in transparency activities and can increase the accountability of each of its performance to be better and continue to grow.

Every apparatus in the sub-district and kelurahan then at the Governance Section of the Regional Secretariat of the City of Bandung can disseminate information to Bandung residents about the SIP Bandung Champion program by distributing it in news, social media or cooperation in service activities, each sub-district and kelurahan can inform the assessment activities to its citizens so that service can be more optimal.

\section{REFERENCES}

\section{Book}

[1] Alamsyah, Kamal. (2016). Public Policy Concepts and Applications. Cet I, Bandung: Media Citra Mandiri Press

[2] Anggara, Sahya. (2018). Introduction to Public Policy. Cet II, Bandung: CV. Librarian Setia Mukarom, Zaenal\&Muhibudin Wijaya Laksana, (2015).

[3] Public Service Management, Volume 1, Cet I, Bandung : CV. Faithful Library

[4] Muhammad. (2019). Introduction to State Administration (Vol. 148). Volume I, Cet I, Sulawesi: Unimal Press

[5] Sellang, Kammaruddin (2016). Administration and Public Service Between Theory and Its Application, Volume I, Yogyakarta: Publisher Ombak

\section{Journal}

[6] Abdal. (2015). "Public Policy (Understanding the Concept of Public Policy)". DigiliUinsgd,

[7] Ahmad, AW, Muspawi, M., Ariesmansyah, A., Chakim, MHR, \& Yodiansyah, H. (2021). Identification of Data-Based Public Administration Governance Strategies: Opportunities and Challenges.Budapest International Research and Critics Institute (BIRCI-Journal): Humanities and Social Sciences,4(4).

[8] Akbar, Muhammad Firyal. (2018). "Description of Organizational Culture in Muhammadiyah Charities (Case Study of Muhammadiyah University of Gorontalo)". Aristo Journal of Public Service Analysis, (2018)

[9] Amanda, Permatasari Iman. "Public Policy (Theory, Analysis, Implementation and Evaluation of Policies)". TheJournalish: Social and Government, 1. (2020)

[10] Ariesmansyah, A., Lestari, AH, Yodiansyah, H., Chakim, MHR, \&Junaedi, IWR (2021). Creativity to Innovation: What Lesson Learned from Digital Transformation in Financial Accountability in Government 
Practices.Budapest International Research and Critics Institute (BIRCI-Journal): Humanities and Social Sciences, $4(4)$.

[11] Bongdan and Taylor, "Introduction to Qualitative Research Methods", DigilibUnimed (2002).

[12] Damanik, YenchiliaTresna, MaromAufarul, "Evaluation of Poverty Reduction Policies through Skills Training Programs in Mangunharjo Village, Tembalang District, Semarang City". Journal of Public Policy and Management Review, 2016

[13] Darmanto, "Understanding Curriculum Administration". Open University Libraries, 2020

[14] Djuanda, "Implementation of Educational Program Evaluation", Journal of Stitalamin, 2020

[15] Hadiyanti, Rini (2013). "Implementation of Government Regulation Number of City Government Regional Apparatus". E-Journal of Government Science

[16] Halimah, Noor, Deli Anhar and Normajatun, "Quality of Public Services at the Department of Population and Civil Registration of Tanah Bumbu Regency", UniskaEprints, November 2019

[17] Kawengian, Debby D. "Evaluation of Northern Policies on Prevention and Eradication, Trafficking in Persons (Trafficking), Especially Women and Children in South Minahasa Regency, Sulawesi Province". Acta Diurna, IV 1,2011

[18] Komarudin, Ruddy, "Impact of Certification on the Performance of Citizenship Education Teachers in the City of Bandung". Upi Edu Repository, 2013

[19] Munthe, Asion. "The Importance of Program Evaluation in Educational Institutions: An Introduction, Understanding, Objectives and Benefits". Scholaria : Journal of Education and Culture, 5(2), (2015).

[20] Marliani, Lina, "Definitions of Administration in Various Perspectives". Unigal Journal, 2019

[21] Novarinda, Wuri, “Training Conducted at Daarul Jannah Cottage Syari'ah Bandung”, Repository, 2017 